\title{
Karakteristik pasien benda asing trakeobronkial di bagian T.H.T.K.L Rumah Sakit Dr. Mohammad Hoesin Palembang
}

\author{
Puspa Zuleika, Abla Ghanie \\ Departemen Telinga Hidung Tenggorok - Bedah Kepala Leher \\ Fakultas Kedokteran Universitas Sriwijaya/ \\ Rumah Sakit Umum Pusat Dr. Mohammad Hoesin \\ Palembang
}

\begin{abstract}
ABSTRAK
Latar belakang: Aspirasi benda asing ialah masuknya benda yang berasal dari luar atau dalam tubuh, ke saluran trakeobronkial. Aspirasi benda asing saluran trakeobronkial merupakan keadaan darurat yang memerlukan tindakan bronkoskopi segera untuk mencegah komplikasi yang lebih serius. Tujuan: Mengidentifikasi karakteristik klinis pasien aspirasi benda asing saluran trakeobronkial di bagian Telinga Hidung Tenggorok - Bedah Kepala Leher (T.H.T.K.L) Fakultas Kedokteran Universitas Sriwijaya/ Rumah Sakit Dr. Mohammad Hoesin Palembang. Metode: Penelitian ini merupakan penelitian observasional deskriptif. Sampel penelitian ini diambil dari data rekam medis pasien aspirasi benda asing pada saluran trakeobronkial di Rumah Sakit Dr. Mohammad Hoesin Palembang periode Januari 2012 - Desember 2016. Hasil: Didapatkan 20 pasien dengan riwayat teraspirasi benda asing di saluran trakeobronkial. Dijumpai 9 orang laki-laki dan 11 orang perempuan dengan perbandingan 1:1,2, di mana usia $0-15$ tahun merupakan penderita terbanyak aspirasi benda asing ini. Benda asing yang paling banyak ditemukan adalah mainan dan benda plastik sebanyak 9 kasus, serta jarum pentul sebanyak 6 kasus. Sebanyak 19 pasien diketahui terdapat riwayat tersedak benda asing. Pemeriksaan foto toraks menunjukkan gambaran normal pada 12 pasien. Lokasi benda asing terbanyak ditemukan di trakea sebanyak 8 kasus. Kesimpulan: Aspirasi benda asing di saluran trakeobronkial sering terjadi pada anak-anak yang berusia kurang dari 15 tahun. Benda asing terbanyak adalah anorganik berupa mainan dan benda plastik. Pemeriksaan radiologi paru dalam 24 jam pertama setelah kejadian aspirasi pada umumnya menunjukkan gambaran normal. Lokasi benda asing di saluran trakeobronkial terbanyak pada penelitian ini adalah di trakea.
\end{abstract}

Kata kunci: Aspirasi, bronkoskopi, foto toraks, benda asing, traktus trakeobronkial

\section{ABSTRACT}

Background: Foreign body aspiration is the entrance of foreign objects from outside or inside of the body into the tracheobronchial tract. Aspiration of foreign body in tracheobronchial tract is an emergency condition that needs immediate bronchoscopy procedure to prevent serious complications. Objectives: To identify clinical characteristics of foreign body aspiration patients in ENT Department Sriwijaya Medical Faculty / Dr. Mohammad Hoesin Hospital, Palembang. Method: This study was a descriptive observational study. The sample of this study was taken from the medical record of tracheobronchial foreign body aspiration patients at Dr. Mohammad Hoesin Hospital from January 2012 until December 2016. Result: There were twenty patients with the history of foreign body aspiration in tracheobronchial tract, consisted of 9 male and 11 female, with the ratio 1:1,2, in which 0-15 year-old children were the majority of the patients. The most common foreign bodies were toys and plastic objects in 9 cases and head veil pin in 6 cases. Nineteen cases of the patients had the history of choking as presenting symptom. Chest X-Ray showed normal imaging on twelve patients. The most common site in tracheobronchial tract where foreign bodies found was the trachea, in eight cases. Conclusions: Foreign body aspirations in tracheobronchial tract were most frequently happened in children less than 15 year-old. The most common foreign bodies were anorganic material, such as toys and plastic objects. Lung X-Rays on the first 24 hours commonly showed normal imaging. Foreign bodies in tracheobronchial tracts most frequently were found in the trachea.

Keywords: Aspirations, bronchoscopy, chest X-Ray, foreign body, tracheobronchial tree 


\section{Alamat korespondensi:}

Puspa Zuleika, MD, Departement of Otorhinolaryngology Head \& Neck Surgery, Sriwijaya University/ Moehamad Hoesin General Hospital, Jenderal Sudirman KM 3.5 Sekip jaya Kemuning Palembang Indonesia, Tel: +6281328384219; E-mail: puspazuleika@yahoo.com.

\section{PENDAHULUAN}

Aspirasi benda asing ialah masuknya benda yang berasal dari luar tubuh atau dari dalam tubuh ke saluran napas. ${ }^{1,2}$, Benda asing pada saluran napas merupakan keadaan darurat yang memerlukan penanganan segera. Keterlambatan penanganan dapat meningkatkan terjadinya komplikasi bahkan kematian. ${ }^{1,2}$ Aspirasi benda asing di bronkus sering menyebabkan gangguan pernapasan dan menjadi penyebab morbiditas dan mortalitas yang tinggi, karena dapat mengakibatkan gangguan napas akut, penyakit paru kronis, dan bahkan kematian. Umumnya terjadi pada anak usia antara 6 bulan sampai 4 tahun dengan puncaknya pada umur 1-2 tahun. Diperkirakan aspirasi benda asing merupakan penyebab 7\% kematian mendadak pada anak di bawah usia 4 tahun. Di Amerika Serikat, pada tahun 2006 terdapat 4.100 kasus $(1,4$ per 100.000) kematian anak yang disebabkan aspirasi benda asing di jalan napas. ${ }^{2,3}$

Diagnosis dan penatalaksanaan merupakan hal penting yang harus dilakukan, untuk mencegah mortalitas dan komplikasi pada kasus aspirasi benda asing. Sangat penting untuk dibuat diagnosis akurat dan tepat waktu, serta pengangkatan benda asing secara aman. Diagnosis ditegakkan berdasarkan anamnesis yang baik, pemeriksaaan fisik, dan pemeriksaan radiologi. Akan tetapi, karena tanda dan gejala tidak khas maka hal tersebut menyebabkan masalah. Kasus aspirasi benda asing sering terlambat didiagnosis karena episode tercekik (choking) awal tidak diketahui, dan gejala lanjut aspirasi benda asing menyerupai kondisi lain, seperti asma, pneumonia rekuren, infeksi saluran napas atas, dan batuk persisten. ${ }^{4}$
Manifestasi klinis aspirasi benda asing bervariasi, dapat berubah seiring dengan perjalanan waktu, dan bisa diinterpretasikan berbeda oleh pemeriksa yang berbeda. Aspirasi benda asing dapat menyebabkan asfiksia, rasa tercekik, batuk paroksismal dengan disertai distress pernapasan, mengi, takipnea, dan dispnea. Setelah episode akut, manifestasi klinis bervariasi dari gejala dan tanda minimal hingga gejala obstruksi jalan napas total. Foto toraks merupakan modalitas utama untuk diagnosis benda asing padat atau logam di saluran trakeobronkial. Selain itu, foto toraks juga berguna untuk menentukan lokasi benda asing dan menilai apakah telah terjadi komplikasi respirasi. ${ }^{2,4,5}$ Keterlambatan diagnosis menyebabkan kelainan patologis paru kronis tanpa didahului oleh gagal napas akut, serta pembentukan granuloma intrabronkial. Aspirasi benda asing juga dapat menyebabkan kelainan kronis jika tidak ditatalaksana dengan cepat. ${ }^{2,5}$

Penatalaksanaan benda asing saluran napas memiliki berbagai modalitas tindakan yaitu laringoskopi, bronkoskopi serat optik, bronkoskopikaku,dantorakotomi.Penggunaan bronkoskopi dalam penatalaksanaan kasus ini menurunkan tindakan pembedahan torakotomi. Bronkoskopi kaku merupakan baku emas penatalaksanaan aspirasi benda asing pada percabangan trakeobronkial yang tampak secara langsung. Bronkoskopi kaku merupakan pilihan untuk ekstraksi benda asing yang teraspirasi pada anak karena ventilasi lebih terjamin, yaitu mempunyai konektor yang dihubungkan dengan oksigen, sehingga lebih mudah untuk melakukan tindakan dan bisa untuk mengatasi perdarahan. Intervensi awal menggunakan bronkoskopi kaku diikuti dengan ekstraksi menggunakan cunam (grasping forcep) atau ekstraktor magnetik 
memungkinkan pengangkatan benda asing dengan mudah dan aman. ${ }^{1,4,6}$

Distribusi lokasi benda asing saluran napas lebih sering dijumpai pada bagian proksimal (90\%) dibandingkan bagian distal. Benda asing saluran napas lebih sering dijumpai pada sistem bronkus kanan (52\%)., ${ }^{1,3}$ Al-Sarraf $\mathrm{dkk}^{4}$ melaporkan bahwa predileksi tersering tersangkutnya benda asing di saluran napas adalah bronkus utama kanan (32\%), diikuti oleh bronkus utama kiri (23\%), lobus kanan bawah (17\%), trakea (17\%), dan lobus kiri bawah (11\%). Jaiswal $\mathrm{dkk}^{7}$ juga melaporkan bahwa benda asing saluran napas lebih banyak dijumpai di bronkus utama kanan (42-70\%), disusul dengan bronkus utama kiri $(18,7-$ $32,6 \%)$, trakea $(27,5 \%)$, bronkus segmental kanan (22\%), laring (1-7,5\%), dan bronkus segmental kiri (3\%). Hal ini disebabkan oleh bronkus kanan hampir membentuk garis lurus dengan trakea, sedangkan bronkus kiri membuat sudut dengan trakea. Selain itu, bronkus kanan mempunyai diameter lebih besar. ${ }^{1,3}$

Pada individu dewasa, benda asing yang teraspirasi cenderung terperangkap di bagian tengah dalam trakea $(53 \%)$ atau distal karina (47\%). Sebagian besar benda asing melewati pita suara dan masuk ke cabang trakeobronkial. Hanya $12 \%$ benda asing yang mengalami impaksi di laring. ${ }^{5}$

Tujuan penelitian adalah untuk mengetahui gambaran karakteristik penderita benda asing di saluran trakeobronkial di bagian Telinga Hidung Tenggorok - Bedah Kepala Leher (T.H.T.K.L) Rumah Sakit Umum Pusat (RSUP) Dr. Mohammad Hoesin.

\section{METODE}

Penelitian ini menggunakan metode observasional deskriptif. Data berasal dari data rekam medis pasien di Bagian T.H.T.K.L. RSUP Mohammad Hoesin Palembang. Waktu penelitian dilakukan pada Januari 2012 sampai Desember 2016. Sampel penelitian adalah semua pasien yang dicurigai teraspirasi benda asing dan dilakukan tindakan bronkoskopi periode Januari 2012 sampai dengan Desember 2016. Deskripsi data pasien meliputi jumlah, usia dan jenis kelamin pasien, jenis benda asing, keluhan pasien saat berobat, hasil pemeriksaan radiologik dan lokasi benda asing intraoperatif. Hasil penelitian disajikan secara deskriptif dalam bentuk narasi dan tabel.

\section{HASIL}

Dari data rekam medis pasien periode Januari 2012 sampai dengan Desember 2016 didapatkan 20 pasien yang dicurigai mengalami aspirasi benda asing di saluran trakeobronkial dan dilakukan tindakan bronkoskopi. Berdasarkan jenis kelamin dari 20 pasien, didapati jumlah pasien laki-laki 9 orang dan perempuan 11 orang, dengan rasio 1:1 (tabel 1).

Pasien yang datang berobat dengan rentang usia 6 bulan hingga 60 tahun. Usia terbanyak pasien yang mengalami aspirasi benda asing adalah kelompok usia anak-anak dengan rentang usia 6 bulan sampai 13 tahun sebanyak 18 orang dan 2 orang pasien berusia 43 tahun dan 60 tahun (tabel 1).

Tabel 1. Karakteristik pasien benda asing saluran trakeobronkial berdasarkan jenis kelamin

\begin{tabular}{lccc}
\hline Tahun & Laki-laki & Perempuan & N \\
\hline 2012 & $2 / 9$ & $3 / 11$ & 5 \\
2013 & $1 / 9$ & $2 / 11$ & 3 \\
2014 & $3 / 9$ & $2 / 11$ & 5 \\
2015 & $2 / 9$ & - & 2 \\
2016 & $1 / 9$ & $4 / 11$ & 5 \\
\hline Total & 9 & 11 & 20 \\
\hline
\end{tabular}

Tabel 2. Penderita benda asing trakeobronkial berdasarkan aktivitas saat tertelan

\begin{tabular}{lr}
\hline Aktivitas & N \\
\hline Bermain & $12 / 20$ \\
Memakai jilbab & $5 / 20$ \\
Tertawa & $2 / 20$ \\
Makan & $1 / 20$ \\
\hline Total & 20 \\
\hline
\end{tabular}


Tabel 3. Jenis benda asing yang teraspirasi

\begin{tabular}{llc}
\hline \multicolumn{2}{c}{ Jenis benda asing } & Insiden \\
\hline Benda asing & Mainan dan benda plastic & $9 / 20$ \\
anorganik & Jarum pentul & $6 / 20$ \\
& Paku & $1 / 20$ \\
& Gigi palsu & $1 / 20$ \\
Benda asing & Kacang tanah & $2 / 20$ \\
organik & Biji petai & $1 / 20$ \\
\hline & Total & 20
\end{tabular}

Tabel 4. Lokasi benda asing berdasarkan temuan intraoperatif

\begin{tabular}{ll}
\hline \multicolumn{1}{c}{ Lokasi } & N \\
\hline Trakea & $8 / 20$ \\
Bronkus kanan & $6 / 20$ \\
Bronkus kiri & $6 / 20$ \\
\hline Total & 20
\end{tabular}

Tabel 5. Waktu antara kejadian aspirasi dan mencapai rumah sakit

\begin{tabular}{|c|c|}
\hline Durasi (hari) & $\mathbf{N}$ \\
\hline$<1$ & 11 \\
\hline 2 & 4 \\
\hline 3 & 1 \\
\hline 4 & 1 \\
\hline 5 & 2 \\
\hline$>6$ & 1 \\
\hline Total & 20 \\
\hline
\end{tabular}

Berdasarkan aktivitas yang dilakukan saat kejadian, bermain adalah aktivitas yang paling banyak, yaitu sebanyak 12 pasien (tabel 2).

Berdasarkan jenis benda asing yang tertelan, dibagi menjadi dua kelompok yaitu benda asing organik dan anorganik. Benda asing anorganik merupakan jenis benda asing terbanyak yaitu 17 kasus, sedangkan benda asing organik sebanyak tiga kasus. Jenis benda asing terbanyak adalah mainan dan benda yang terbuat dari plastik, yaitu sembilan kasus diikuti dengan jarum pentul sebanyak enam kasus. Benda asing organik terdiri dari kacang tanah sebanyak dua kasus dan biji petai satu kasus (tabel 3).
Dari anamnesis didapatkan keluhan utama yang paling banyak dijumpai adalah tersedak benda asing sebanyak 19 pasien, dan hanya satu pasien yang datang dengan keluhan utama batuk.

Pemeriksaan radiologi berupa foto toraks merupakan pemeriksaan penunjang yang wajib dilakukan pada pasien yang datang dengan keluhan aspirasi benda asing. Sejumlah 12 pasien dengan gambaran paru normal. Hanya satu pasien dengan gambaran paru pneumonia disertai dengan gambaran benda asing dengan riwayat tersedak benda asing sejak 16 hari sebelum masuk rumah sakit.

Berdasarkan lokasi temuan benda asing intraoperatif, lokasi benda asing di saluran trakeobronkial yaitu delapan benda asing di trakea dan masing-masing sebanyak enam benda asing di bronkus kanan dan bronkus kiri (tabel 4).

Sebelas orang pasien segera ke rumah sakit setelah mengalami kejadian aspirasi dan satu orang mengalami keterlambatan diagnosis hingga 16 hari (tabel 5).

\section{DISKUSI}

Aspirasi benda asing merupakan keadaan gawat darurat yang dapat berakibat fatal, dan dapat terjadi pada semua usia terutama pada bayi dan anak usia kurang dari 3 tahun. Hal ini disebabkan antara lain karena pertumbuhan gigi molar yang belum sempurna, kecenderungan anak untuk memasukkan benda ke dalam mulut, dan seringkali berteriak, menangis atau berteriak dengan benda asing dalam mulut. Menurut Rovin $\mathrm{dkk}^{8}$, lebih dari $50 \%$ kasus aspirasi benda asing terjadi pada anak dengan usia kurang dari 3 tahun, dan sekitar 75\%-85\% kasus terjadi pada anak di bawah usia 15 tahun. Pada kelompok dewasa, aspirasi benda asing lebih sering terjadi pada usia lebih dari 60 tahun. Hal tersebut disebabkan oleh karena proteksi jalan napas pada usia tersebut tidak adekuat. ${ }^{9}$ Pada penelitian ini, 12 pasien 
aspirasi benda asing di saluran trakeobronkial adalah anak berusia kurang dari 10 tahun, dengan kejadiannya hampir sama baik pada laki-laki maupun perempuan yaitu 1:1,2. Perempuan lebih banyak mengalami aspirasi benda asing saluran trakeobronkial. Hal ini mungkin disebabkan karena pemakaian jarum pentul untuk memasang jilbab pada perempuan. Terdapat perbedaan dengan penelitian yang lain di mana laki-laki lebih sering dibanding dengan perempuan. Saki dkk ${ }^{10}$ di Rumah Sakit Apadana, Iran, melaporkan suatu penelitian yang luas dari tahun 1988 hingga 2008 dan melaporkan angka kejadian aspirasi benda asing pada laki-laki sebanyak 644 orang $(63,5 \%)$ dan perempuan 371 orang $(36,5 \%)$.

Berdasarkan jenis benda yang teraspirasi, dapat dibagi menjadi organik dan anorganik. Benda asing organik bersifat menyerap cairan kemudian mengembang, dan sejalan dengan waktu akan mengakibatkan pembengkakan yang cepat, yang mengakibatkan perubahan derajat obstruksi, dari obstruksi parsial menjadi total. Selain itu benda asing organik menimbulkan reaksi inflamasi yang berat dalam beberapa jam. Benda asing organik yang sering teraspirasi adalah kacang dan biji buahbuahan. ${ }^{8,11}$ Sedangkan benda asing anorganik memberikan tanda dan gejala yang lebih ringan daripada organik. Benda asing anorganik yang sering teraspirasi adalah manik-manik, mainan kecil, jarum, tutup pulpen, serta peralatan sekolah ukuran kecil. ${ }^{11}$ Pada penelitian ini benda asing yang teraspirasi paling banyak adalah benda asing non organik berupa mainan plastik sebanyak 9 pasien.

Pada penelitian ini didapatkan 19 orang pasien datang ke rumah sakit dengan keluhan utama tersedak benda asing. Hal ini dikarenakan pasien atau orang tua pasien menyadari dan menyaksikan kejadian tersedak ini. Hanya satu pasien yang datang dengan keluhan batuk dan riwayat tersedak benda asing tidak diketahui. Diagnosis aspirasi benda asing ditegakkan dengan melakukan anamnesis yang teliti kepada saksi yang melihat kejadian tersebut, namun sering kali tidak terdapat saksi mata. Anamnesis yang khas untuk aspirasi benda asing di saluran trakeobronkial adalah batuk yang paroksismal, sesak napas yang tiba-tiba, dan kebiruan di sekitar mulut, hal ini ditemukan pada lebih $90 \%$ kasus. ${ }^{8,11}$

Setiap kasus yang diduga aspirasi banda asing harus dilakukan pemeriksaan radiologi. Pemeriksaan radiologi terutama berguna untuk mendeteksi gejala yang ditimbulkan oleh benda asing tersebut karena pada kebanyakan kasus aspirasi benda asing bersifat radiolusen. Pada 24 jam pertama, pemeriksaan radiologi sering menunjukkan tidak adanya kelainan. ${ }^{8,9,11}$ Kaur dkk dikutip Tamin $\mathrm{dkk}^{11}$ melaporkan hasil foto Rontgen toraks pada aspirasi benda asing didapatkan gambaran paru normal 32\%, pergeseran mediastinum 20\%, konsolidasi $20 \%$, emfisema $16 \%$, dan benda asing radiopak $6 \%$. Pada penelitian ini didapatkan $60 \%$ pemeriksaan foto Rontgen memberikan gambaran paru yang normal. Hal ini dapat disebabkan karena penderita tersebut datang ke rumah sakit dalam waktu kurang dari 24 jam sehingga belum terjadi kelainan pada paru. Selanjutnya, 35\% pasien menunjukkan adanya gambaran benda asing radiopak, dan 10\% menunjukkan telah terjadi kelainan pneumonia pada gambaran foto Rontgen paru.

Pada penelitian ini, sebelas pasien datang ke rumah sakit dalam waktu kurang dari 24 jam setelah kejadian tersedak benda asing. Penegakan diagnosis dan pengambilan benda asing sebaiknya dilakukan secepatnya untuk mencegah terjadinya sekuele pada saluran trakeobronkial. ${ }^{12}$ Keterlambatan diagnosis aspirasi benda asing dapat terjadi karena orang tua yang tidak waspada dengan gejala aspirasi, atau pada pemeriksaan dokter melewatkan gejala klinis aspirasi dan gambaran radiologi. Pada penelitiannya, Saki ${ }^{10}$ melaporkan dari 1015 pasien, 269 pasien (26,6\%) ditatalaksana kurang dari 24 jam pasca aspirasi, dan 846 pasien $(73,4 \%)$ ditatalaksana lebih dari 24 jam. 
Szafranski ${ }^{13}$ melakukan penelitian di Polandia pada tahun 1978-2008 dan melaporkan terdapat dua belas pasien dengan benda asing bronkus yang mengalami keterlambatan penatalaksanaan.

Lokasi benda asing yang teraspirasi tergantung dari bentuk dan ukurannya serta posisi pasien pada saat terjadi aspirasi. ${ }^{14}$ Secara statistik, persentase aspirasi benda asing berdasarkan lokasinya masing-masing adalah hipofaring sebanyak $5 \%$, laring/trakea sebanyak $17 \%$, dan bronkus sebanyak 78\%. Lokasi benda asing yang terbanyak adalah terdapat di bronkus utama kanan, karena posisi bronkus utama kanan membentuk sudut 25 derajat ke kanan dari garis tengah, sedangkan bronkus utama kiri membentuk sudut 45 derajat ke kiri dari garis tengah. ${ }^{8,9,11}$ Pada penelitian ini benda asing lebih banyak ditemukan di trakea yaitu sebanyak delapan pasien, sementara bronkus kanan dan bronkus kiri memiliki jumlah pasien yang sama yaitu 6 orang. Benda asing yang tersangkut di trakea ini berupa mainan plastik dan jarum pentul. Dari hasil intraoperatif ditemukan bahwa ukuran mainan plastik seperti peluit dan ujung pulpen mengakibatkan benda asing tersebut tersangkut di trakea, sementara benda asing yang lain berupa jarum pentul yang ujung tajamnya tertancap pada mukosa trakea sehingga posisi jarum pentul tidak berubah.

Benda asing di saluran trakeobronkial merupakan suatu keadaan darurat yang memerlukan penanganan segera. Puncak kejadian terjadi pada usia anak-anak terutama kurang dari 15 tahun, dengan perbandingan kejadian laki-laki dan wanita yaitu 1:1,2. Benda asing terbanyak yang teraspirasi adalah benda asing anorganik berupa mainan dan benda plastik sebanyak 9 orang. Pemeriksaan radiologi paru harus dilakukan pada pasien teraspirasi benda asing untuk mengetahui bentuk, ukuran dan lokasi benda asing serta komplikasi yang timbul. Pemeriksan radiologi paru yang diambil dalam waktu 24 jam pertama setelah kejadian aspirasi biasanya menunjukkan gambaran normal. Lokasi benda asing di saluran trakeobronkial terbanyak pada penelitian ini adalah di trakea sebanyak 8 pasien. Bronkoskopi kaku merupakan baku emas ekstraksi benda asing, dengan pertimbangan pernapasan lebih terkontrol, oksigenasi adekuat, lumen lebih besar sehingga memudahkan melakukan tindakan, serta untuk mengatasi bila terdapat perdarahan.

\section{DAFTAR PUSTAKA}

1. Ragab A, Ebied OM, Zalat S. Scarf pins sharp metallic tracheobronchial foreign bodies: presentation and management. 2007; 71(5): $769-73$.

2. Cohen S, Avital A, Godfrey S, Gross M, Kerem E, Springer C. Suspected foreign body inhalation in children: What are the indications for bronchoscopy? J Pediatr. 2009; 155(2): 276-80.

3. Junizaf MH. Benda asing di saluran napas. Dalam: Seopardi EA, Iskandar N, Bashiruddin J, Restuti RD, editor. Buku Ajar Ilmu Kesehatan Telinga Hidung Tenggorok Kepala \& Leher. Jakarta: Balai Penerbit Fakultas Kedokteran Universitas Indonesia; 2010. h. 259-65.

4. Al-Sarraf N, Eddine HJ, Khaja F, Ayed AK. Headscarf pin tracheobronchial aspiration: a distinct clinical entity. Interactive CardioVascular and Thoracic Surgery. 2009; 1(1): 187-90.

5. Ghai A, Wadhera R, Hooda S, Kamal K, Verma V. Subglottic foreign bodies-two case reports. Anesth, Pain \& Intensive Care. 2008; 12(1): 27-9.

6. Fitri F, Prijadi J. Bronkoskopi dan ekstraksi jarum pentul pada anak. Jurnal Kesehatan Andalas. 2014; 3(3): 538-44.

7. Jaiswal AA, Garg AK. Spontaneous expulsion of foreign body (Seewing Machine Needle) from right middle lobe bronchus - A rare case report. Journal of Clinical and Diagnostic Research. 2014; 8(8): 1-2.

8. Rovin JD, Rodgers BM. Pediatric foreign body aspiration. Pediatrics in Review. 2000; 21(3): 86-90. 
9. Dickensoy O, Usalan C, Filiz A. Foreign body aspiration: clinical utility of flexible bronchocscopy. Postgrad Med J. 2002: 78(921): 399-403.

10. Saki N, Nikakhlagh S, Rahim F, Abshirini H. Foreign body aspirations in infancy: A 20-year experience. International Journal of Medical Sciences. 2009; 6(6): 322-8.

11. Tamin S, Hadjat F, Abdillah F. Penatalaksanaan aspirasi biji jeruk di traktus trakeobronkial dengan berbagai manifestasi klinis. Jurnal Oto Rhino Laryngologica Indonesiana. 2005; $35: 16-25$.
12. Donato L, Neus L, Brig J. Tracheobronchial foreign bodies. Archives Pediatr. 2000: 7(1): 565-615.

13. Szafrański W, Dobielski J, Papiewski W, Czechowska U. Occult bronchial foreign bodies - analysis of own material. Polandia: Regional Specialistic Radom Hospital. 2013; 81(1): 40-4.

14. Tahir N, Ramsden WH, Stringer MD. Tracheobronchial anatomy and the distribution of inhaled foreign bodies in children. Eur $\mathbf{J}$ Pediatr. 2009: 168(3):289-5. 